\title{
Prevalence of otological symptoms and parafunctional habits in patients with temporomandibular dysfunction
}

\author{
Bianca Lopes Cavalcante de Leão ${ }^{1}$ \\ https://orcid.org/0000-0002-6170-1914 \\ Flavia Carolina Trentini Gabriel ${ }^{2}$ \\ https://orcid.org/0000-0002-4541-8115 \\ Kaliane Rodrigues da $\mathrm{Cruz}^{2}$ \\ https://orcid.org/0000-0003-3641-4531 \\ Amanda Luquesi Kagawa ${ }^{2}$ \\ https://orcid.org/0000-0002-0747-4001 \\ Bianca Simone Zeigelboim ${ }^{1}$ \\ https://orcid.org/0000-0003-4871-2683 \\ José Stechman-Neto ${ }^{1}$ \\ https://orcid.org/0000-0002-0259-2420
}

Universidade Tuiuti do Paraná, Programa de Pós-Graduação em Distúrbios da Comunicação

Universidade Tuiuti do Paraná, Faculdade de Ciências Biológicas e Saúde Faculdade de Ciências Biológicas e Saúde, Curso de Odontologia.

Conflict of interests: Nonexistent

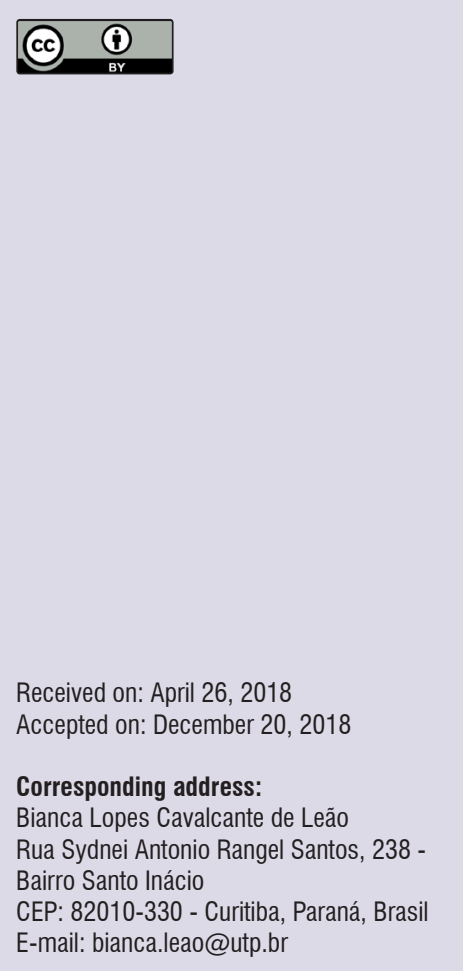

\section{ABSTRACT}

Objective: to verify the relationship between otological symptoms and parafunctional habits in individuals with temporomandibular joint dysfunction.

Methods: evaluations were based on the clinical records of 768 patients treated at a temporomandibular joint diagnostic center from 2010 to 2016. The inclusion criteria were completely filled out charts of adult patients ( $>18$ years of age) and the final sample comprised 516 clinical records. The presence/absence of parafunctional habits and otological symptoms (tinnitus, hearing impairment, dizziness, the sensation of plugged ears and imbalance) was recorded.

Results: statistically significant associations were found between otological symptoms and both sex and the presence of parafunctional habits, as otological symptoms were more prevalent among women and individuals with at least one parafunctional habit.

Conclusion: in the present sample, otological symptoms were positively associated with parafunctional habits in individuals with temporomandibular joint dysfunction.

Keywords: Ear; Habits; Temporomandibular Joint; Tinnitus; Temporomandibular Joint Dysfunction Syndrome 


\section{INTRODUCTION}

The American Academy of Orofacial Pain defines temporomandibular joint dysfunction or temporomandibular disorders (TMD) as a set of clinical conditions that affect the masticatory muscles, the temporomandibular joint and associated structures. The most frequent symptoms reported by affected individuals are facial pain, pain in temporomandibular joint and masticatory muscles, and headache. The auditory system can also be affected and variety of otological symptoms are reported..$^{1-3}$ TMD has a multifactor etiology, which includes trauma, degenerative problems, parafunctional habits, an abnormal position of the condyle and joint disc, excessive activity of the masticatory muscles as well as social and psychological variables. ${ }^{4}$

Otological symptoms are frequent in individuals with TMD, and the most commonly cited in the literature are tinnitus (ringing in the ears), dizziness, vertigo, earache and a sensation of ear fullness. ${ }^{1,5-7}$ Some theories state that hyperactivity of the masticatory muscles generates problems in the stomatognathic system and, due to the anatomical proximity, the inner ears can be affected. ${ }^{2,8}$

Parafunctional habits are defined as any nonfunctional neuromuscular activity of the stomatognathic system resulting from the repetition of an action that is considered pleasant by the individual exercising it. A parafunctional habit may be a response to an emotional need and causes hyperactivity of the masticatory muscles. When such activity surpasses the level of physiological tolerance, a negative impact on the stomatognathic system can occur. $^{9}$

The relationship between otological symptoms and parafunctional habits should be evaluated to assist in the correct diagnosis and treatment of individuals with TMD. Therefore, the aim of the present study was to determine the relationship between otological symptoms and parafunctional habits in individuals with TMD.

\section{METHODS}

This study received approval from the Human Research Ethics Committee of Universidade Tuiuti do Paraná (certificate number: 2.131.007) in 2016. Evaluations were performed of the clinical charts of 768 patients treated between 2010 and 2016 at a temporomandibular joint diagnostic center of a private university in the city of Curitiba, Brazil. The inclusion criteria were completely filled out charts of adult patients ( $>18$ years of age). Among the 768 charts analyzed, 252 did not meet the inclusion criteria. Therefore, the sample was composed of 516 clinical charts of patients

The following data were recorded: sex, age, presence/absence of patient-reported parafunctional habits (biting the tongue, cheeks, lips, nails or objects, chewing gum, clenching/grinding the teeth) and presence/absence of patient-reported otological symptoms (tinnitus, hearing impairment, dizziness, sensation of plugged ears and imbalance). The results were tabulated and submitted to descriptive statistics (calculation of frequencies) and bivariate analysis with the aid of SPSS 20.0 Statistics IBM ${ }^{\circledR}$.

\section{RESULTS}

Analyzing the 516 medical records 421 (81.58\%) of whom were women, and 95 (18.41\%) were men. Mean age was 42.03 years (range: 18 to 84 years. A total of $494(95.7 \%)$ patients reported having at least one parafunctional habit, and $393(76.16 \%)$ reported having at least one otological symptom, the most common of which was tinnitus, reported by $138(26.74 \%)$ patients. Statistically significant associations were found between otological symptoms and both sex and the presence of parafunctional habits, as otological symptoms were more prevalent among women and individuals with at least one parafunctional habit (Table 1).

A significant association was also found between age and otological symptoms, as those with such symptoms had a higher mean age compared to those without symptoms (Table 2). 
Table 1. Distribution of habits and otological symptoms $(n=516)$, Curitiba, Paraná, 2017

\begin{tabular}{ccccc}
\hline & & $\begin{array}{c}\text { Absence of otological } \\
\text { symptoms (\%) }\end{array}$ & $\begin{array}{c}\text { Presence of otological } \\
\text { symptoms (\%) }\end{array}$ & $\mathbf{p}^{*}$ \\
\hline \multirow{2}{*}{ Sex } & Males & $33(6.39 \%)$ & $62(12.01 \%)$ & $\mathbf{0 . 0 1 1}$ \\
\hline \multirow{2}{*}{ Presence of habits } & Females & $90(17.44 \%)$ & $331(64.14 \%)$ & $\mathbf{0 . 0 0 5}$ \\
\hline
\end{tabular}

*chi-square

Table 2. Distribution of patients in relation to age and the presence of otological symptoms ( $N=516)$, Curitiba, Paraná, 2017

\begin{tabular}{ccccccc}
\hline \multirow{2}{*}{ Otological symptoms } & \multicolumn{9}{c}{ Age } & Mreq (\%) & Mean (SD) & Median & Mín. & Max. & $\mathbf{p}^{*}$ \\
\cline { 2 - 7 } & $377(75.40 \%)$ & $42.81(15.43)$ & 42 & 16 & 84 & $\mathbf{0 . 0 4 9}$ \\
\hline Presence & $123(24.60 \%)$ & $39.64(14.59)$ & 39 & 16 & 72 & \\
\hline
\end{tabular}

*Mann-Whitney Freq = Frequence; SD = standard deviation; Min = lowest value found; Max = Maximum value found.

\section{DISCUSSION}

In the present study, the mean age was higher among the individuals with a greater prevalence of otological symptoms compared to those without such symptoms. This finding is in agreement with data reported in a previous study involving a sample of individuals aged 60 years or older, in which the risk of otological symptoms increased with age. ${ }^{2}$ Similar evidence is reported in studies involving the general population, in which all forms of otological symptoms were found. to increase proportionally with the advance in age..$^{2,10-12}$ This may be explained by anatomic and physiological factors $=$ Anatomic and physiological factors may explain this Physiological ageing may be linked to a degenerative process of the cochlea, which is one of the structures of the inner ear, explaining the greater incidence of otological symptoms in older individuals. . $^{13,14}$

A statistically significant association was found between otological symptoms and the presence of parafunctional habits in the present study, as otological symptoms were more prevalent among the individuals who reported having at least one parafunctional habit. Similar results are reported in a previous study, in which the majority of individuals had at least one otological symptom and at least one parafunctional habit, and an association was also found between the symptom of ear fullness and number of parafunctional habits. ${ }^{15,16}$

The authors of a study conducted in 2016 found a statistically significant association between TMD and parafunctional habits, the most prevalent of which was nail-biting. ${ }^{17}$ Another study also found a high prevalence of parafunctional habits in the population studied and found a relationship between parafunctional habits and temporomandibular joint dysfunction, which are similar to the present findings. ${ }^{18}$

The authors of a systematic review point out that TMD can cause harm to the auriculotemporal nerves and intra-tympanic pressure; the authors also report that trigger point mechanisms may be related to these otological symptoms. ${ }^{19}$

Tinnitus is a clinical symptom commonly found in patients with TMD. This condition is reported to stem from external ear disorders, such as otosclerosis, chronic otitis, the side effects of medications and abnormal conductivity of the nerve of the neural tube..$^{19,20}$ According to the literature, the high prevalence of tinnitus among studies may be related to the motor activity of the stapedius muscle, which, when undergoing spasms, causes vibrations in the ossicles of the middle ear, or tinnitus may stem from intra-capsular disorders of the temporomandibular joint due to its connection to the middle ear. ${ }^{13,21}$ In the present study, tinnitus was the most prevalent otological symptom, reported by 122 of the patients.

In the present study, otological symptoms and parafunctional habits were more prevalent in women than in men. This is in agreement with findings described in previous studies, in which the larger portion of the sample was composed of women. ${ }^{6,7,12,20,22-27}$ To explain 
this finding, some authors have proposed a possible relationship between TMD and mechanisms of pain modulation, since women exhibit greater sensitivity to pain, as well as environmental, social and cultural factors. ${ }^{16,22,27,28}$

\section{CONCLUSION}

A positive association was found between otological symptoms and parafunctional habits in patients with temporomandibular joint dysfunction. These symptoms may be directly related to the parafunctional habits practiced by these individuals and have been described as predisposing or even triggering factors for TMD. Dentists should take prevention measures and provide counseling on parafunctional habits to patients presented with TMD. The awareness of these habits should be addressed, in order to avoid future systemic, psychological and social consequences.

\section{REFERENCES}

1. Ramirez LM, Ballesteros LE, Sandoval GP. Otological symptoms among patients with temporomandibular joint disorders. Rev. Med. Chile. 2007;135(12):1582-90.

2. Bernhardt O, Gesch D, Schwagn C, Bitter K, Mundt $T$, Mack $F$ et al. Sings of temporomandibular disorders in tinnitus patients and in a populationbased group of volunteers: results of the study of health in pomerania. J Oral Rehabil. 2004;31(4):311-9.

3. Leeuw R. Dor orofacial: guia de avaliação, diagnóstico e tratamento. 4aㅡ ed. São Paulo: Quintessence; 2010

4. Machado IM, Pialarissi PR, Minici TD, Rotondi J, Ferreira LP. Relações dos sintomas otológicos nas disfunções temporomandibulraes. Arq. Int. Otorhinolaryngol. 2010;14(3):274-9.

5. Lam DK, Lawrence HP, Tenenbaum HC. Aural symptoms in temporomandibular disorder patients attending a craniofacial pain unit. J Orofac Pain. 2001;15(2):146-57.

6. Kusdra PM, Stechman-Neto J, Cavalcante-Leao BL, Martins PFA, Lacerda ABM, Zeigelboim BS. Relationship between otological symptoms and TMD. Int Tinnitus J. 2018;22(1):30-4.

7. Skog C, Fjellner J, Ekberg E, Häggman-Henrikson B. Tinnitus as a comorbidity to temporomandibular disorders - a systematic review. J Oral Rehabil. 2018. doi: 10.1111/joor.12710.
8. Myrhaug $\mathrm{H}$. The incidence of ear symtoms in cases of malocclusion and temporomandibular joint disturbances. Br J Oral Surg. 1964;2(1):28-32.

9. Gavish A, Halachmi M, Winocur E, Gazit E. Oral habits and their association with sings and symptoms of temporomandibular disorders in adolescent girls. J Oral Rehabil. 2000;27(1):22-32.

10. Camparis CM, Formigont G, Teixeira MJ, Siqueira JTT. Clinical evaluation of tinnitus in patients with sleep bruxism: prevalence and characteristics. J Oral Rehabil. 2005;32(11):808-14.

11. Felício CM, Oliveira JAA, Nunes LJ, Jeronymo LFG, Jeronymo RRF. Alterações auditivas relacionadas ao zumbido no distúrbios otológicos e da articulação temporomandibular. Rev Bras Otorrinolaringol. 1999;65(2):141-6.

12. Medeiros SP, Batista AUD, Forte FDS. Prevalência de sintomas de disfunção temporomandibular e hábitos parafuncionais em estudantes universitários. RGO. 2011;59(2):201-8.

13. Gelb H, Gelb ML, Wagner ML. The relationship of tinnitus to craniocervical mandibular disorders. Cranio. 1997;15(2):136-43.

14. Vasconcelos BC, Barbosa LM, Barbalho JC, Araújo GM, Melo AR, Santos LA. Ear pruritus: a new otologic finding related to temporomandibular disorder. Gen Dent. 2016;64(5):39-43.

15. Felício CM, Faria TG, Silva MAMR, Aquino AMCM, Junqueira CA. Desordem temporomandibular: relações entre sintomas otológicos e orofaciais. Rev Bras Otorrinolaringol. 2004;70(6):787-95.

16. Paulino MR, Moreira VG, Lemos GA, Silva PLP, Bonan PRF, Batista AUD. Prevalence of signs and symptoms of temporomandibular disorders in college preparatory students: associations with emotional factors, parafunctional habits, and impact on quality of life. Cien Saude Colet. 2018;23(1):173-86.

17. Agarwal K, Saha S, Sinha P. Prevalence of temporomandibular disorders and its association with parafunctional habits among sênior-secondary school children of lucknow, India. J Indian Ass Pub Health Dent. 2017;14(2):139-43.

18. Fernandes G, Franco-Micheloni NA, Siqueira JTT, Gonçalves DAG, Camparis CM. Parafunctional habits are associated comulatively to painful temporomandibular disorders in adolescents. Braz Oral Res. 2016;30(1):e30.

19. Stechman NJ, Porporatti AL, Toledo IP, Costa YM, Conti PCR, Canto GL et al. Effect of 
temporomandibular disorder therapy on otologic signs and symptoms: a systematic review. $\mathrm{J}$ of Oral Rehabil. 2016;43(6):468-79.

20. Porto De Toledo I, Stefani FM, Porporatti AL, Mezzomo LA, Peres MA, Flores-Mir $C$ et al. Prevalence of otologic signs and symptoms in adult patients with temporomandibular disorders: a systematic review and meta-analysis. Clin Oral Investig. 2017;21(2):597-605.

21. Maciel LFO, Landim FS, Vasconcelos BC. Otological findings and other symptoms related to temporomandibular disorders in young people. $\mathrm{Br}$ J Oral Maxillofac Surg. 2018;56(8):739-43.

22. Magalhães BG, Freitas JL, Barbosa AC, Gueiros MC, Gomes SG, Rosenblatt A et al. Temporomandibular disorder: otologic implications and its relationship to sleep bruxism. Braz $\mathrm{J}$ Otorhinolaryngol. 2018;84(5):614-9.

23. Zocoli R, Mota EM, Sommavilha A, Perin RL. Manifestações otológicas nos distúrbios da articulação temporomandibular. Arquivos Catarinenses de Medicina. 2007;36(1):90-5.

24. Cauás M, Alves IF, Tenório K, HC Filho JB, Guerra CMF. Incidências de hábitos parafuncionais e posturais em pacientes portadores de disfunção da articulação craniomandibular. Rev Cir Traum Buco. 2004;4(2):121-9.

25. Uemoto L, Macedo MEG, Alfaya TA, Souza FN, Barcelos R, Gouvêa CVD. Impacto da terapia de suporte nas alterações otológicas em pacientes com desordem temporomandibular. Rev Dor. 2012;13(3):208-12.

26. Bortolleto PPB, Moreira APSM, Madureira $P R$. Análise dos hábitos parafuncionais e associação com disfunção das articulações temporomandibulares. Rev Assoc Paul Cir Dent. 2013;67(3):216-21.

27. Ferreira CLP, Silva MAR, Felício CM. Signs and symptoms of temporomandibular disorders in women and men. CoDas. 2016;28(1):17-21.

28. Huang GJ, LeResche L, Critchlow CW, Martin $M D$, Drangsholt MT. Risk factors for diagnostic subgroups of painful temporomandibular disorders. J Dent Res. 2002;81(4):284-8. 